\title{
Peter McKinlay
}

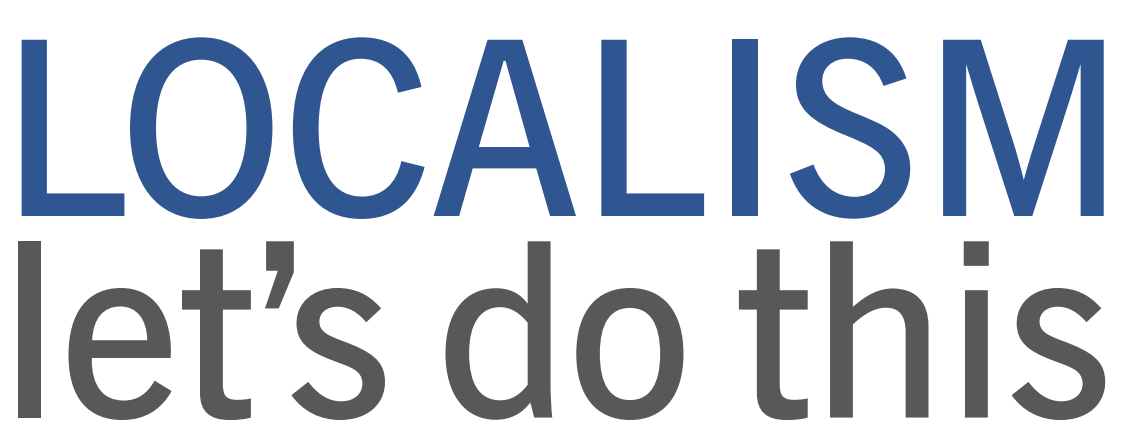

\section{Abstract}

This article explores the emergence of localism as a key concept in local governance. It distinguishes between devolution, subsidiarity and localism, and examines how current policy development in New Zealand still reflects a very top-down understanding of governance. It then argues that local government has all the powers required to put in place a radical practice of localism and explains how.

Keywords localism, governance, devolution, subsidiarity, delegation, communities, well-being, purpose

$\mathrm{T}$ his article is a reflection on localism. It culminates in the argument that New Zealand local government already has all of the power and authority required to adopt a radical policy of localism. It discusses what is understood by localism and whether New Zealand councils have the political will and capability to lead change.

Any discussion of localism should start with recalling Humpty Dumpty's classic statement, in Through the Looking Glass:
'When I use a word,' Humpty Dumpty said in rather a scornful tone, it means just what I choose it to mean - neither more nor less.'

'The question is,' said Alice, 'whether you can make words mean so many different things.'

'The question is,' said Humpty Dumpty, 'which is to be master - that's all.'
A useful beginning: the UK Localism Act 2011

The story begins with the United Kingdom's Localism Act 2011, which at the time was promoted as a significant shift in the locus of power. The Act itself does not define localism, but the responsible minister, the minister of state for decentralisation, in his forward to A Plain English Guide to the Localism Act had this to say:

I have long believed there is a better way of doing things. Eight years ago I wrote a book called Total Politics which set out the case for a huge shift in power - from central Whitehall, to local public servants, and from bureaucrats to communities and individuals.

Today, I am proud to be part of a Government putting this vision into practice. We think that the best means of strengthening society is not for central government to try and seize all the power and responsibility for itself. It is to help people and their locally elected representatives to achieve their own ambitions. This is the essence of the Big Society. (Department for Central and Local Government, 2011, p.1)

Sadly, performance did not live up to the promise. The community right to

Peter McKinlay, Executive Director of McKinlay Douglas Ltd and Director of the Local Governmen Think Tank, has nearly 30 years' experience as a researcher and adviser on local governance and local government. He is a fellow of the RSA and a Senior Associate with the Institute for Governance and Policy Studies. 
challenge, which was presented as an opportunity for communities to put forward to councils alternative approaches for delivering services with the expectation that the community might then be able to take over the service delivery role itself, turned out to be simply a way of triggering a competitive process for tendering service production, almost the direct opposite of what localism was understood to offer.

Despite that, interest in localism in the United Kingdom has continued to increase. This article will draw on two recent UK think tank reports, one reflecting the view that localism is central to the future of good governance, the other to provide an in-depth view of how the public sector as a whole needs to change through radical empowerment of communities in order to address alienation and manage the exponential growth in demand for public services.

\section{Local Government New Zealand and Project Localism}

In New Zealand there has been a relative lack of interest in localism, until the launch in 2018 of Local Government New Zealand's Localism project, which is so far primarily a call for substantial devolution from central government to local government of major governmentprovided services, along with the funding required to meet the cost of those services. This project is still in its early stages, so it is not yet clear what view it will take of localism.

\section{Localism considered}

An informed discussion of localism needs to unbundle a number of different but often conflated concepts, including devolution, subsidiarity, and localism itself.

Localism is not so much about formal institutional power, as about influence and the right to share in decision making. This was spelt out in a 2018 report from the English think tank Locality, People Power: findings from the Commission on the Future of Localism. Locality had established the commission in 2017 to consider 'how to reinvigorate localism and unlock the power of community'. The commission was chaired by Lord Kerslake, the president of the Local Government Association and previously the head of the Home Civil
Service. The report had this to say about the characteristics of localism:

Localism must be about giving voice, choice and control to communities who are seldom heard by our political and economic institutions. Localism should enable local solutions through partnership and collaboration around place, and provide the conditions for social action to thrive. Localism is about more than local governance structures or decentralising decisionmaking. It is about the connections and feelings of belonging that unite people within their communities. It is about ideally the resources) to make decisions about and undertake a particular activity or activities, but crucially subject to whatever conditions the higher tier seeks to impose. In an extreme, devolution can increase dependency on the higher tier rather than build autonomy within the lower tier.

\section{International comparisons}

New Zealand is an outlier, with a relatively narrow range of functions and relatively low proportion of public expenditure undertaken by local government, compared with the much more extensive responsibilities of local government in

\section{Greater involvement in major service delivery does not necessarily mean greater authority and discretion for local government.}

how people perceive their own power and ability to make change in their local area alongside their neighbours. (Commission on the Future of Localism, 2017, pp.3, 7)

Subsidiarity, which is often confused with localism, is the principle that decisions should be taken at the lowest level which encompasses the principal impact of the decision. Subsidiarity encompasses both deciding and implementing and thus requires an implementation capability. Localism, in contrast, as the Commission on the Future of Localism states, is about voice, choice and control. This may and should influence implementation, but does not necessarily involve undertaking implementation as such. The difference is critical. In practice subsidiarity would place authority with local government, as it is local government which typically has the implementation capability. In contrast, localism would place authority in the hands of the community or communities affected, empowering them to share in decision making so that their voices shape the outcomes which result.

Finally, devolution involves a higher tier passing to a lower tier the authority (and
European jurisdictions, North America and the UK. Councils in those jurisdictions are typically responsible for a much broader range of service delivery for their communities, and spend a significantly greater proportion of GDP, and of public expenditure, than is the case with local government in New Zealand. To a great extent this reflects the quite significant differences between the history of local government in those jurisdictions and in New Zealand, where the reality of our history is that centralism was the only option.

Greater involvement in major service delivery does not necessarily mean greater authority and discretion for local government. The English experience of councils having major service delivery responsibilities is a combination of ongoing central government intervention in service delivery, and major reductions in services as central government treats funding for local government as a discretionary item of expenditure which can be cut back to meet central government's budgetary objectives. The English experience is a dramatic illustration of the risk for local government in carrying the responsibility, often statutory, for the 
delivery of major services when much of the associated funding is provided through a central government grant which is discretionary rather than entrenched.

\section{People Power}

This report's statement on localism, quoted above, is reflective of an increasing trend in local governance, especially within the UK and North America, of recognising the importance of creating means for people and communities who have felt excluded from the political process to re-engage and have a genuine voice in helping shape their own futures. services need radical change and how it can be achieved, despite the fact that apart from a single reference to the Localism Act 2011 this report makes no explicit reference to localism.

The New Local Government Network's basic thesis is that public services in the sense of services to support people and communities have evolved through three successive paradigms and are now entering a fourth. These are described as: the civic paradigm, lasting from the 16th to the early 20th century and based on an evolving patchwork of independent bodies delivering limited public services; the state

\section{... with the additional strength of making the case that a shift to a new paradigm is necessary not just in terms of restoring democratic engagement, but also in order to manage burgeoning demand.}

This trend has seen innovative developments in the use of existing powers, as with the creation of Wiltshire Council's area boards. ${ }^{1}$ These are technically subcommittees of the council, with significant delegated authority, each centred around a former market town and comprising ward councillors for the area. In practice, and by the council's constitution, area board meetings are open to anyone within the area who wishes to attend and take part in decision making, which the constitution provides should be by consensus if at all possible while still recognising that legally the only formal decision makers are the ward councillors. The structure underpins a number of collaborative arrangements between the council and its communities and has led to a significant level of mutually beneficial co-production and co-governance activity.

\section{The community paradigm}

Locality's People Power report is complemented by a February 2019 report from the New Local Government Network, The Community Paradigm: why public paradigm from the 1940s to the early 1980s, providing universal, comprehensive, free at the point of use provision (in the UK the post-Beveridge report reforms; in New Zealand the development of the welfare state); and the market paradigm from the 1980s and now reaching the end of its era of influence, focused on cost and efficiency and based on a transactional approach to relationships between the state and providers, and providers and users.

The New Local Government Network argues that the market paradigm, and the state paradigm, the hierarchic approach of which is still pervasive, are unable either to address a growing sense of alienation amongst much of the public, or to build the collaborative and egalitarian relationships needed to create the preventative approach that can stem rising demand. Its position is:

there is an urgent need for a new model of public service delivery: the Community Paradigm. The fundamental principle underpinning this paradigm is to place the design and delivery of public services in the hands of the communities they serve. In this way, a new, egalitarian relationship can be built between public servants and citizens: one that enables the collaboration necessary to shift to prevention; one that requires communities to take more responsibility for their own well-being; and one that means citizens and communities can genuinely 'take back control'. (New Local Government Network, 2019, p.7)

The balance of the report makes a strong evidence-based case for shifting greater control to communities themselves, including developing 'community commissioning' of public services. It is in the spirit of People Power in arguing for the importance of voice, choice and control, but with the additional strength of making the case that a shift to a new paradigm is necessary not just in terms of restoring democratic engagement, but also in order to manage burgeoning demand. In this respect its basic argument about the prerequisites for the sustainability of public services points in the exact opposite direction to the present New Zealand government's emphasis on further centralisation (reform of the State Sector Act, restructuring of the polytechnic and industry training organisation sector, the role of the new New Zealand Infrastructure Commission, initiatives in urban development).

\section{Local governance for community well-being}

The present government came to office with a commitment to resetting relationships between central government and local government. This has included introducing legislation to restore to the Local Government Act 2002 the purpose of promoting community wellbeing, and beginning to consider how the government's own well-being policy, including the application of the Treasury's Living Standards Framework and the introduction of a well-being budget, can mesh with local government's forthcoming role of promoting community well-being.

In November 2018 the minister of local government took a paper to cabinet on the theme of local governance for community well-being which invited cabinet: 
to agree to consider the future role of local governance in New Zealand in delivering intergenerational wellbeing for all New Zealanders, delivering regional growth objectives, strengthening local democracy and instilling greater trust and confidence in local governance. (Office of the Minister of Local Government, 2018, p.1)

The paper included the following description of localism, confusing localism with subsidiarity:

'Localism' is a concept underpinned by the principle that 'public services should be provided by the sphere of government which is as close as possible to the people who use and benefit from the services, unless there are reasons why they should be provided by governments at a regional national sphere'. (ibid., p.6)

This suggests central government and its advisors are on something of a learning curve about the nature of localism and of the role of communities in governance, as well as in understanding the inherent difference between subsidiarity and localism. It is likely that its authors were unaware of developments in the practice of localism internationally, including the emergence of a number of innovative community governance initiatives. Instead, as the following paragraphs illustrate, it appears to have been written on the assumption that central government intervention, and, potentially, legislative change, will be required to support a stronger emphasis on community governance:

I will take a principle-based consideration of the role local leadership could play in delivering intergenerational wellbeing for all New Zealanders, strengthening local democracy, instilling greater trust and confidence in local governance and supporting regional development.

I propose to explore a paradigm of local governance that is empowered to develop localised initiatives to tackle areas of concern such as hazard and risk management, social enterprise, young people not participating in trade, work or education, barriers to employment, and homelessness and social housing.

My reform programme seeks to reposition local government with a stronger more wellbeing focussed role within our communities; strengthen the legitimacy of local government and the level of civic participation within our communities; and importantly, to manage the cost pressures faced by local
12(2) of the Act, which provides that:

For the purposes of performing its role, a local authority has -

a) full capacity to carry on or undertake any activity or business, do any act, or enter into any transaction; and

b) for the purposes of paragraph (a), full rights, powers, and privileges.

The next step is to consider section $10(1)$. This section is currently being amended; its provisions are stated here on the assumption that the amendment has

\section{A number of responses outlined different approaches to working with communities which went well beyond the formal statutory requirements of the Act, but none demonstrated a policy commitment to enabling decision making and action by communities.}

government to make rates more affordable - particularly in terms of the provision of water infrastructure. (ibid., pp.7-8)

Inherent in the minister's proposal is the continuance of an approach in which specifying local government's role and function should remain centrally determined.

There are, it needs to be noted, areas where central government action will be required - for example, addressing some of the challenges of local government funding and financing - but, as the following overview of provisions in the Local Government Act demonstrates, local government already has all of the statutory powers needed to lead a radical shift in local governance, empowering communities to become major partners in decision making.

Local governance and the Local Government Act

Understanding the powers of local government should begin with section become law. The section states that:

The purpose of local government is -

a) to enable democratic local decision-making and action by, and on behalf of, communities; and

b) to promote the social, economic, environmental, and cultural well-being of communities in the present and for the future.

Arguably, section 10(1)(a), with its purpose of enabling democratic local decision making and action by communities, is already a charter for supporting community governance.

The new purpose will be given more precision by the inclusion of a new decision-making rule which will require councils, when taking a decision, to consider the likely impact of the decision on each aspect of community well-being. It seems certain that this will mean councils will need to understand not just the broad effects of well-being at the level of the socalled 'four well-beings', but the impact on different aspects of each well-being something which will require them to take 
positive steps to develop suitable wellbeing indicators for local communities.

Section 11 of the Act, addressing the role of the local authority, provides that it is to 'give effect, in relation to its district or region, to the purpose of local government stated in section 10'. In other words, it is to give effect to, among other things, the purpose of promoting democratic local decision making and action by communities.

As part of the research for this article, all councils were asked to respond to a brief questionnaire, the principal question in which was: 'Does your council explicitly recognise the purpose of enabling decision- responsibilities, duties, or powers except -'; the exceptions relate primarily to striking a rate, borrowing, purchasing or disposing of assets (unless provided for in the longterm plan), appointing a chief executive, making a bylaw, or adopting a long-term plan, annual plan or annual report.

Community boards are established (or disestablished) with the approval of the Local Government Commission and are elected by people within the area of the community board. Committees are much more flexible as structures. Clause 31 of schedule 7 provides a broad power to establish committees or subcommittees

\section{There is much uncertainty, and a lot of talking past each other, taking place in the evolution of understandings of localism, community governance, well- being and the respective roles of central and local government.}

making and action by communities?' A number of responses outlined different approaches to working with communities which went well beyond the formal statutory requirements of the Act, but none demonstrated a policy commitment to enabling decision making and action by communities. Some had delegated authority to various community committees and other bodies to undertake limited activity, but this was more to meet the functional requirements of the council than to promote genuine communitybased decision making. Others had adopted quite creative approaches in going beyond the formal statutory requirements for consultation, but all without exception reserved final decision making to the council itself.

Other provisions in the Local Government Act enable extensive delegation of authority. Clause 32 of schedule 7 enables a local authority to delegate 'to a committee or other subordinate decision-making body, community board, or member or officer of the local authority any of its and appoint people who are not elected members of the local authority. In practice the majority of the members of a committee or subcommittee can be non-members, as the schedule simply requires that at least one member be an elected member. There is, thus, broad authority for councils to establish committees drawn from the community and delegate very significant powers to them. A council doing this would have complete discretion in determining how the community should be identified. It could, for example, follow the practice long used in Portland, Oregon with its residents' associations of establishing a set of criteria by which the council would recognise self-identifying communities, a practice which has proved very effective.

There is no particular guidance in the Act on how people should be chosen to become members of a committee or subcommittee other than that, in the opinion of the local authority, 'that person has the skills, attributes, or knowledge that will assist the work of a committee or subcommittee'. It would be quite consistent with this provision for a council to decide to establish a committee to take major responsibility for activity within a given community and invite that community to share with the council both in choosing the members of the committee and in determining its terms of reference.

A council thus has two statutory options for taking the initiative in sharing significant decision-making power with its communities. The first is community boards, and the second committees. The first has the advantage of providing a wellknown mechanism for selecting members - election as part of the triennial electoral process - but the disadvantage of being subject to the formal establishment provisions of the Local Government Act, including prescriptive provisions for determining the community a board represents. The latter is far more flexible, but does require councils to be skilled in determining how best to work with communities and creating what would be seen as genuinely representative bodies.

A further option, and one followed by a number of councils internationally, is to facilitate the establishment by communities themselves of representative bodies for the purpose of working with the council and undertaking any activities which may be delegated by it.

\section{The powers exist. Why aren't they used? How to change this?}

There is no easy answer. Current practice seems to be partly a matter of culture, partly a matter of history, partly a matter of the attitude of successive central governments, and partly one of understandings within the sector itself of the respective roles of councils and communities.

Local Government New Zealand's position statement on localism states:

Instead of relying on central government to decide what is good for our communities it is time to empower councils and communities themselves to make such decisions. Strengthening self-government at the local level means putting people back in charge of politics and reinvigorating our democracy. (Local Government New Zealand and the New Zealand Initiative, n.d.) 
On the face of it this reads like a sector commitment to involving communities more closely in decision making. Whether this will indeed prove to be the case should become clearer when Local Government New Zealand releases its Localism discussion paper in July 2019.

The combination of the statutory framework for promoting community well-being and current, especially international, understandings of wellbeing policy and practice suggest that the Local Government Act's new purpose should amount to a statutory mandate for local government to become the advocate and facilitator for ensuring the effectiveness of major service design and delivery within its communities, effectively making the Act a charter for promoting localism.

A number of factors militate against local government recognising the role now potentially open to it. First, its traditional practice, including the nature of the statutory consultation process, has been more consistent with representative than with participatory democracy. Second, central government attitudes have fluctuated considerably. Labour-led governments have tended to take a positive attitude to local government, enabling community involvement and promoting well-being. In contrast, National-led governments have put more emphasis on core services, discouraging councils from innovating in areas such as social and economic well-being. The lack of a consistent view over successive central governments has unquestionably encouraged councils to take a risk-averse and conservative approach to expanding their mandate despite their legal powers to do so.

Another barrier is the relative lack of knowledge within New Zealand local government both of the arguments in support of greater community involvement (including the potential for generally positive outcomes for councils themselves), and of the many and varied options for enabling community involvement in decision making.

The minister's linking of local governance and community well-being should be the catalyst for change. The opportunity is for local government, and other stakeholders interested in promoting community governance, to seize the opportunity the minister's initiative presents and demonstrate both that the necessary legislative powers already exist, and that the best results come when community governance is treated as a bottom-up approach to empowerment, not a top-down approach to some form of guided democracy. All that now stands between our current top-down approach to governance and communities, and genuine localism, is political will on the part of New Zealand's councils.

\section{Conclusion}

There is much uncertainty, and a lot of talking past each other, taking place in the evolution of understandings of localism, community governance, well-being and the respective roles of central and local government. A pessimist could see this as evidence that New Zealand's public sector will be unable to move away from its entrenched top-down approach to dealing with communities. An optimist (this author is one) sees this more in terms of a gradual coalescence of a coalition of the willing who collectively will facilitate a major shift in the governance of New Zealand, from top-down to bottom-up and collaborative.

\footnotetext{
1 Wiltshire Council is what is known as a unitary council serving a population of approximately 450,000 people in south-east England.
}

\section{References}

Commission on the Future of Localism (n.d.) People Power: findings from

the Commission on the Future of Localism - summary report, London:

Locality and Power to Change, https://locality.org.uk/wp-content/ uploads/2018/03/LOCALITY-LOCALISM-REPORT-1.pdf

Department for Central and Local Government (2011) A Plain English

Guide to the Localism Act, London: Department for Central and Local

Government, https://assets.publishing.service.gov.uk/government/

uploads/system/uploads/attachment_data/file/5959/1896534.pdf

Local Government New Zealand and the New Zealand Initiative (n.d.)

'Local government position statement in localism', https://www.lgnz.
co.nz/assets/Uploads/4853d04950/46672-LGNZ-Localism-launchdocument.pdf

New Local Government Network (2019) The Community Paradigm: why public services need radical change and how it can be achieved, http:// www.nlgn.org.uk/public/2019/the-community-paradigm-why-publicservices-need-radical-change-and-how-it-can-be-achieved/

Office of the Minister of Local Government (2018) Local Governance for Community Wellbeing, https://www.dia.govt.nz/diawebsite.nst/Files/ Central-Local-Government-Partnerships/\$file/CLGP-Cab-paperNovember-2018.pdf 